\title{
MEMOIR
}

\section{ROBERT HORNBY WOFFINDIN}

ROBERT HORNBY WOFFINDIN was killed, with two of his senior officials, in a car accident in July last, at the early age of 57 . At the time of his death he was President, for the year 1950-5I, of the Actuarial Society of South Africa, General Manager and Actuary of the African Life Assurance Society Ltd. (having held that appointment since I938), a Director of the African Guarantee and Indemnity Company, Ltd., and of the African Boiler and Engineering Insurance Company, Ltd., and an alternate Director of the National Finance Corporation of South Africa. He was a past Deputy Chairman of the Life Offices' Association of South Africa and a past Vice-President of the Insurance Institute of the Transvaal, and had also been Chairman of the South African Employers' Association.

All these bodies will miss his wise and courteous counsel, but none will do so more than the small band of actuaries working in Southern Africa. Each of us knows that his passing has deprived our young Society of probably its deepest source of real knowledge of the various races which make up our many-coloured community-knowledge that was acquired along the hard road of experience with no text-book to chart the way, but which was freely given to all who cared to ask.

Born in London, Mr Woffindin first joined the Sun Life Insurance Office there and was an enthusiastic member of the Royal Naval Reserve. During the r914-I 8 War he was on almost continuous sea-going service-rising to the rank of Lieutenant Commander-and completion of his examinations was delayed until his rejoining the Sun. Shortly afterwards, in 1925, he came to South Africa as Actuary of the African Life at a time when little was really known of the vital statistics of the non-European races. Every step forward had to be carefully considered, tested and proved safe before the next step was thought out, and it was during this period that he laid the permanent foundation upon which his ultimate wealth of practical experience was so surely based.

He was one of those rare persons whose strength of character was such that he never saw the slightest need for an unkind word, far less for a discourteous deed, whether dealing with his staff, his friends or his competitors in business.

He was truly a man who held himself a debtor to his profession and was a help and an ornament thereto; and by that simple code, allied to the charm of a completely upright nature, he leaves behind an army of friends and none who ever wished him ill.

F. G. 